\title{
Learning and reporting system in a tertiary university hospital compared to the Austrian-wide open access system
}

\author{
Gerald Sendlhofer ${ }^{1,2^{*}}$, Brigitte Kober ${ }^{1}$, Karina Leitgeb ${ }^{1}$, Monika Schanbacher ${ }^{3}$ \\ From Safety in hospitals: from strategy to implementation Annual Scientific Meeting 2015 \\ Graz, Austria. 29-30 September 2015
}

\section{Background}

Learning and reporting systems (LRS) are used worldwide to support patient safety aspects in healthcare. The goal of a LRS is to increase patient safety on an organizational level as well as in a global manner. However, a LRS can be used in different ways, on the one hand near misses are reported which could have been harmful to patients and on the other hand adverse or sentinel events can also be found in LRS. Furthermore, within Europe differences between countries are eminent, for example in Great Britain the system is used very frequently whereas in Austria a LRS is just used occasionally.

In Austria, a national LRS was implemented and is accessible by the public since 2010 [1]. Within the University Hospital Graz, a LRS was implemented in 2013. The aim of this report is to compare the in-house versus the open access LRS.

\section{Material and methods}

In-house: The LRS was piloted for one year in a unit and after evaluation opened in 2013 for all departments and all employees. The LRS is easy to access via the intranet-starting page. Reports are reviewed according to internal guidelines and results of each anonymous report are published in the intranet after a reasonable time. Prior implementation the LRS was promoted in information meetings and within the employees' newspaper and e-newsletter.

Open access: The Austrian-wide national LRS can be used by anyone who has access to the internet. Ongoing

\footnotetext{
* Correspondence: gerald.sendlhofer@klinikum-graz.at

'Department of Quality and Risk Management, University Hospital Graz, Graz, Austria

Full list of author information is available at the end of the article
}

reports are sent to experts. The national LRS was promoted within the healthcare community and the public.

\section{Results}

Within the in-house LRS 121 reports were handled by the reviewer since September 2013. Within six years of being online 452 incidents were reported to the national LRS, thereof 365 were published in the internet (Table 1).

\section{Conclusions}

Over a period of 11 years the NHS LRS implicates that approximately 2,000 incidents are reported per day $(60,000$ per month) by healthcare professionals to the

Table 1. Number of reports in the nation-wide and inhouse LRS

\begin{tabular}{|c|c|c|}
\hline Indication & In-house & Open-access \\
\hline Reports (n) & 121 & 365 \\
\hline \multicolumn{3}{|l|}{ Top 3 of who reported (\%) } \\
\hline Nurse & 38 & 21 \\
\hline Physician & 49 & 56 \\
\hline Medical technical assistants & 4 & 2 \\
\hline \multicolumn{3}{|l|}{ Top 4 disciplines (\%) } \\
\hline General medicine & - & 16 \\
\hline Anesthesia & 11 & 10 \\
\hline Surgery & 46 & 10 \\
\hline Internal Medicine & 25 & 10 \\
\hline \multicolumn{3}{|l|}{ Top 4 where did it happen (\%) } \\
\hline Ward & 27 & 46 \\
\hline Outpatient clinic & 15 & 8 \\
\hline Operating theatre & 20 & - \\
\hline Intensive care unit & 7 & - \\
\hline
\end{tabular}


national LRS [2]. The national LRS of Austria and the in-house LRS receives approximately 6 reports per month. For the national LRS it is obvious, that the LRS is only used by healthcare professionals and not by the public. Reason could be that the national LRS is not well known at all. Overall, the number of reports is very low when compared to NHS-data. Cultural difference between the countries might be the most dominant reason for the low response rate in Austria.

\section{Competing interests}

The authors declare that they have no competing interests.

\section{Acknowledgements}

We would like to thank the entire organization and their employees for supporting patient safety initiatives.

\section{Authors' details}

'Department of Quality and Risk Management, University Hospital Graz, Graz, Austria. ${ }^{2}$ Division of Plastic, Aesthetic and Reconstructive Surgery,

Department of Surgery, Medical University of Graz, Graz, Austria. ${ }^{3}$ Division of Oral and Cranio-Maxillofacial Surgery, Department of Dentistry and

Maxillofacial Surgery, Medical University of Graz, Graz, Austria.

Published: 30 October 2015

\section{References}

1. [http://www.cirsmedical.at], (accessed 26 April, 2015).

2. [http://www.nrls.npsa.nhs.uk/resources/collections/quarterly-data-summaries/, (accessed 26 April, 2015).

doi:10.1186/2056-5917-1-S1-A12

Cite this article as: Sendlhofer et al: Learning and reporting system in a tertiary university hospital compared to the Austrian-wide open access system. Safety in Health 2015 1(Suppl 1):A12.

\section{Submit your next manuscript to BioMed Central} and take full advantage of:

- Convenient online submission

- Thorough peer review

- No space constraints or color figure charges

- Immediate publication on acceptance

- Inclusion in PubMed, CAS, Scopus and Google Scholar

- Research which is freely available for redistribution

Submit your manuscript at www.biomedcentral.com/submit
C Biomed Central 